\title{
'Pull up a good tree and push it outside'? The Rev Edward Tsewu's dispute with the Free Church of Scotland Mission
}

\begin{abstract}
The Tsewu secession or dispute took place in the context of the emergence of African Initiated Churches during the latter part of the nineteenth century as a response to mission Christianity and an assertion of a distinct form of African Christianity. Tsewu's brand of response falls within the genre of the Ethiopian-type church which tended to retain most of the outward expressions of the denominations which they left, eg. liturgy, polity and doctrine. Tsewu led the first secession from the Presbyterian fold in 1896 and this prepared the ground for a further secession in 1898.
\end{abstract}

\section{INTRODUCTION}

There is an assumption (eg. Denis 2010:32) that there was only one secession from the Presbyterian fold in South Africa during the last two decades of the nineteenth century. Within Presbyterianism, the Mzimba secession is relatively well known. What is far less well known is that in 1896, two years prior to Mzimba's secession, there was another disruption to Presbyterian church life in Johannesburg led by Rev Edward Tsewu ${ }^{1}$. This occurred within the context of the growing phenomenon of Ethiopianism as part of the African Initiated Church movement.

\section{THE AFRICAN INITIATED CHURCH MOVEMENT}

During the second half of the nineteenth century there was a rise in protest and resistance against political and economic domination in South Africa. This was linked to the emergence of a black elite who had received their education at mission establishments, 'yet who were progressively restricted in their activities to their own areas' (Duncan 1997:67), and were excluded from white society. Concurrent with the rising tide of protest and resistance in the secular sphere, a movement was coming to birth which grew rapidly in ecclesiastical life, giving expression to feelings of resentment which could not easily be expressed otherwise. This was the African Initiated Church (AIC) movement. While this movement originated as a negative response to ecclesiastical oppression, it had positive features which account for its rapid growth and sustained existence for 'AICs have the potential of embodying a type of Christian spirituality and faith that does not merely contextualize some superficial elements of a Western interpretation of Christianity but rather represents a legitimate version of Christian faith, a nonWestern religion, that has taken root in the distinctive heritage of that continent' (Kärkäinen 2002:195). Whether successful or not, 'Independent Churches have,..., attempted to make a creative synthesis of traditional and Christian beliefs..., they represent radical indigenisation and Africanisation of Christianity' (Motlhabi in Mosala \& Tlhagale [ed] 1986:80). Seen in negative terms, AICs are a protest against 'the experience of religious manipulation, deculturalization and racial subjugation' and in more positive light as 'a part of the broad and long term process

1 I am grateful to Dr Joan Millard, formerly of UNISA, for this insight offered as long ago as 1996 when I was studying for my Master's degree. 
of national politico-economic emancipation (Lamola 1988:6; Claasen 1995:15). AICs were a 'catalyst for this political surge' (Cuthbertson 1987:84) of black nationalism which spread through mission stations towards the end of the nineteenth century. Mission and evangelism in the mission churches had 'separated the gospel from the historical and material context of the people addressed' (Cochrane 1987:156). However,

Both missionaries and Africans were victims of social and political change outwith their control but missionaries showed themselves unable to identify with the African aspirations they had engendered and also unable to liberate themselves from the prejudices and mores of their race and class (Brock 1974 : Abstract)

In sum, it can be said that the AIC movement accommodated Christian beliefs to the realities of black peoples' lives; they related Christianity with black history and identity and were, therefore, 'Ethiopian'; and they wished the organisation of churches to be under the control of blacks.

\section{ETHIOPIANISM}

The roots of Ethiopianism may be traced to the early years of the nineteenth century with the struggle of the anti-colonialist Nxele and the development of African indigenous theology by Ntsikana. Both developed a religious synthesis of African traditional religion and Christianity which 'demonstrate the turbulence in the symbolic world occasioned by the coming of the Europeans...' (De Kock 1996:56). Nxele operated by resistance and Ntsikana by adapting the beliefs of mission Christianity. And so a politically significant movement was born (Cochrane 1987:90) into the context of a self-awareness of oppression. It was a source of challenge to whites' western dominated understanding of the gospel.

Sundkler $(1961: 13,33)$ claims that 'Ethiopian- type' churches 'originated as a result of secession from white churches on political and racial grounds'. While an early secession from the Paris Evangelical Missionary Society occurred in 1872 in Lesotho, in a situation of political instability, it displayed three features of later secessions: 'the resentment of white control, the possible political implications, and the resistance to disciplinary regulations' (Hinchliffe 1968:90).

The actual beginning of Ethiopianism in South Africa is attributed to Rev Nehemiah Tile who left the Wesleyan Missionary Society and formed the Tembu National Church in 1882 . This was the first AIC in South Africa. Tile was followed by Rev Kanyane Napo who left the Anglican Church and formed the African Church in 1891; and then by Rev Mangena Mokone and Rev Samuel James Brander who left the Methodist Church and Anglican churches respectively in 1892 and founded the Ethiopian Church based on the text of Psalm 68:31: 'Ethiopia shall lift up her hands to God'. it was consciously non-tribalistic and was based on 'a philosophy of African self-consciousness and unity' (Lamola 1988:9). Unlike earlier secessions which were 'national' in a tribal sense, the Ethiopian Church was 'national' in a racial sense. Nehemiah Tile defected from the Methodists in 1883; Khanyane Napo from the Anglicans in 1891; Mangena Mokone from the Methodists in 1892; Samuel James Brander from the Anglicans in 1892; Jacob Xaba defected from the Methodists in 1893 and James Mata Dwane from the Methodists, also in 1896. Rev JC Xaba stated the positive aim of Ethiopianism: 'to promote Christianity and unity in the whole continent of Africa' (CE August 1897 in Wilson \& Perrot 1972:155). Its aim was, therefore, not divisive but incorporative with regard to all blacks. This could not take place within the denominationalistic mission churches. The Anglican Church of the Province displayed more insight with regard to the incorporation of the Order of Ethiopia: 'our church would have failed in her duty if she proved incapable of welcoming, arid of comprehending such elements of native thought and devotion as have thus been working out their own development'. This is the church which was composed of: 
a large crowd of natives who had been rejected by other churches as incompetent, or who had seceded from other missions, or who had entered into the ministry in a state utterly incompetent so far as education, training and moral insight were concerned (Pastoral Letter of CPSA, Christian Express [CE] October 1900, in Wilson \& Perrot 1972:157-158).

These were regarded as churches which will be filled with the American 'negro spirit ... [which] is decidedly anti-white. It aims to bring about a cleavage between white and black' (Pastoral Letter of CPSA, CE October 1900, in Wilson \& Perrot 1972:157-158) as if such a division was not already apparent in society. And now blacks are to be blamed for causing it!

A major criticism of the Ethiopian-type churches was that they missionised areas where the mission societies had already worked and drew members away from them. So long as this did not happen their aims were considered to be legitimate. But when they began to proselytise they were accused of having 'no connection with any of the well known Missionary societies, which have done the whole work of planting Christianity among the natives of this country' (CE April 1897, Editorial, in Wilson \& Perrot 1972:153). Ethiopian-type churches have intruded on the territory of 'those societies which have done the real [emphasis mine] missionary work of this country' (J Stewart in CE vol. xxvii April 1, 1897 no.324). Stewart accused the secessionists of 'not doing mission work among the natives'. To a large extent neither did the missionaries for much of the work was done by black evangelists, eg. at Burnshill and Pirie missions, it was black converts who acted as teachers and catechists (Hofmeyr \& Pillay 1994:72). The mission churches clearly saw their work in terms of exclusivity and the Ethiopian movement as an intrusion.

Ethiopianism altered the means of black political protest and challenged 'those who believed in evolutionary change through constitutional means' as they 'were impatient with white control and pessimistic about protest for evolutionary change' (Odendaal 1984:23). It was based on the idea that blacks had a right to self- determination through 'self-pride, self-reliance and service to humanity' (Lamola 1988:9), rejection of the accommodation approach favoured by JT Jabavu's newspaper, Imvo Zabantsundu, and the recognition of a need for economic power. So it was not just a spiritual or ecclesiastical movement as is confirmed by Alexander Roberts of Lovedale's deprecatory assessment at the General Missionary Conference (1904): 'First, it is a race movement; second, it is political; third, it is a church' (Kuzwayo 1979:17 in Lamola 1988:9). However, the Lovedale based Christian Express adopted a reasonably positive attitude to Ethiopianism, suggesting that the AIC movement provided 'meaningful material benefits within a highly exploitative economic environment' (Cochrane 1987:92) although after it began to be affected by it, it changed its attitude as we can see in the lack of perception, bordering on propaganda, displayed in the false assessment: 'The virtual, if not actual, collapse of the Ethiopian Church' (CE vol. xxix, September 1, 1899 no. 349), a view not borne out by the facts or subsequent history. Cuthbertson (1991:64) is correct in seeing Lovedale's 'encounter with Ethiopianism as a formative stage in the rapid politicisation of an African elite'. Lovedale had to bear the result of educating blacks even if it seemed its education was thrown back in its face.

Ethiopianism's political credentials are attested by its rejection of 'the liberal assumptions of a common non-racial society' (Odendaal 1984:xi), and Rev JL Dube's newspaper Ilanga lase Natal as well as in Chief M Majozi's Ipepa lo Hlanga which was considered 'a seditious propaganda organ for the Ethiopian movement' (Lamola 1988:9).

The 'native problem' was the issue of the day and Ethiopianism was part of it being the sole national religio-political body. The Native Affairs Commission (1903-1905) met 'under the cloud of Ethiopianism' and resulted in 'a consequent obligation to give some recognition to the increasing number of educated, civilised Africans' (Brock 1974:335) but with little concern for the remainder who constituted the vast majority of the people. It had enabled several regional organisations to form the South African Natives' National Congress (SANNC) in 1912, despite the 
fact that it had suffered from internal dissension and breakaways, eg. by Reverands S Brander and J Dwane. By the 1920s, numerous groups had broken away from mainstream missionary churches. Lamola (1988:11) argues that the years 1910-30 witnessed a 'new convergence of black political opinion' stemming from black alienation arising out of the Treaty of Union (1910) which 'sealed their inferior political position'. And this fell within 'the classical period of Ethiopianism', i.e., 1882-1928 (Bridgman in Brock 1974:409).

It is clear that Ethiopians saw a convergence of the political and the religious motives and methods. However, in conceiving the reason for the founding of the Black Church as being primarily missiological even to the extent of visualising the principle of the ecumenical dimension of Christian mission, they were the formulators of the concept of Pan-Africanism. They preached that the church in colonial South Africa and the entire African population should he so developed, freed and equipped that it can go out and serve other people, - "Africa for Humanity" (Lamola 1988:12). This appealed to such as Edward Tsewu.

\section{THE TSEWU DISPUTE}

\section{Rev Edward Tsewu}

Edward Tsewu was born in Grahamstown in 1856. He (SANAC IV, 43,754:803) claimed to be 'an Amaxosa, a Gaika'. He was the son of a deacon of the Lovedale congregation of the Free Church of Scotland. He attended school at Gqumahashe village near Lovedale (Millard 1999:73). At the age of fifteen, he went to Lovedale Institution to train as a teacher from 1872-1875 (Lovedale Missionary Institution[LMI] reports 1872:16 [where he is described as coming from Buchanan, a mission situated north of Mthatha], 1873:17, 1874:1717, 1875:18) gaining the Elementary Teacher's Certificate. Moir (1898:2) describes him in retrospect as having made 'creditable efforts to help himself and suffered somewhat from the worldliness of others'. Tsewu then taught at Adelaide. Following the receipt of a call to the ministry, Tsewu returned to Lovedale to study Theology (LMI 1880:27; 1881:25; 1882:20; 1883:35). Despite 'a slight feeling, even then, of uncertainty about him' (Moir 1898:2), he was licensed a probationer of the Free Church and sent to Cunningham mission, Toleni in the Transkei in 1884. In 1886, he was transferred to Idutywa (Millard 1999:73) and Main but 'Nowhere did he do well', according to Moir, and:

when a proposal was made to promote him to a more independent sphere at Johannesburg ... and when the question of his ordination to the full status of a minister was raised in connection with this proposal, the Presbytery did not feel justified in declining, though again some members hesitated (Moir 1898:2).

This 'hesitation' was to have a subsequent problematic outcome for the Presbytery. Another reason for ordaining Tsewu may have been that, between 1856 and 1910, 'only about twentytwo African Presbyterians were ordained' (Switzer 1993:125, 126). This was the heavy price paid for maintaining high educational standards and an unwillingness to ordain men to equal status in ministry (Switzer 1993:123, 125): 'Missionary enthusiasm for ordaining African pastors was declining by the $1880 \mathrm{~s}$, as the arbiters of a segregationist culture began to separate church congregations and limit contact between white and black clergy' (Switzer 1993:125). Consequently, Switzer (1993:187) argues that "[t]he mission's subordination of the ordained clergy, in particular, was a major factor in the schisms'. Stewart must bear some responsibility for this state of affairs for his segregationist views and policies had begun to cause anxiety among church leaders by the 1880 s to the extent that they 'could no longer trust Lovedale and Stewart to act or speak in their best interests' (Brock 1974:344, 345). He and others, Moir included, had been involved in producing men who:

sought a share in the power structure as decision makers - in allocating funds, controlling 
and administering property, choosing suitable candidates for the ministry and promoting them to positions of authority. In short, the ordained African clergy wanted to become equal partners with the missionaries in the ongoing life of mission and church. When they were denied this role, they felt they had no choice but to separate (Switzer 1993:187).

For instance, Rev PJ Mzimba was one of the first graduates in theology (1874) under the system introduced by the new Principal of Lovedale Institution, James Stewart. This was a significant development and change of policy which allowed black ministers trained in South Africa to join the ranks of the Free Church of Scotland Mission. African clergy wanted to upgrade their status through ordination. '[F]inancially strapped parent boards of several mission bodies [including the FCoS] also began urging their missionaries to establish autonomous "self-supporting, self-governing, self-propagating" African churches' opening up to them the 'most prestigious vocations open to the upwardly mobile elite during the colonial period' (Switzer 1993:123). However, there were reservations concerning this policy change. Stewart was unwilling to adhere to Scottish mission policy concerning the ordination of blacks 'In an agitated moment he seems to have claimed that the main cause of Ethiopianism was to be found in the interfering European mission boards in the matter of the ordination of Africans' (Sundkler 1961:39).

\section{The Johannesburg Congregation of the Presbytery of Kaffraria}

In 1890, Rev PJ Mzimba, minister of the Presbytery of Kaffraria of the Free Church of Scotland [CoS] at Lovedale, was sent to Johannesburg to evaluate the work in the Free Church of Scotland congegation there which was mainly composed of young men from the Eastern Province who were migrant labourers. This led to Rev Edward Tsewu being called as minister to the Johannesburg congregation in 1891 (Tsewu to Smith, 31 January 1891, NLS 7797). The Foreign Mission Committee (FMC) of the FCoS refused to take responsibility for this congregation and the Transvaal Presbytery did not want to be involved in this placement, and denied Tsewu a seat in presbytery as well as financial support. As a consequence, the Presbytery of Kaffraria retained responsibility though it was almost impossible to exercise authority from such a great distance. He was subsequently transferred to Johannesburg. His work went quite well until a group in his congregation accused him of 'irregularities' (Millard 1999:73).

\section{The Tsewu Secession}

In the meantime, by 1896, Tsewu was alleged to have become involved in the Ethiopian movement and Mzimba was sent by the Presbytery of Kaffraria to assist in dealing with the problems in the Free Church Mission in Johannesburg led by Tsewu as the result of charges of mismanagement of the congregations affairs 'with a view to worldly gain' (UFH, HPAL, Proceedings of the Synod of Kaffraria of the Free Church of Scotland, July 1897:7). However, Tsewu denied that he was a member of the Ethiopian Church. He informed the South African Native Affairs Commission [SANAC] on 14 October 1904: 'I do not belong to the Ethiopian Church, except the word Ethiopian may mean black. I am a Presbyterian ...' (SANAC IV, 43,618:793). He claimed that often the Ethiopian term is used "by others saying "This is an Ethiopian" as if they were doing something quite apart from other Christian brethren'. He then made a comment that suggested that the missionaries were stirring up emotive responses: 'I do not blame the Government so much as the missionaries, who go to the Government and say, "Look at these people who are rebelling against you"' (SANAC IV, 43,618:793). In this regard he employed the metaphor of a tree: 'pull up a good tree and push it outside' (SANAC, 43,621:793). He regarded this as a great mistake 'without investigating the thing fully, or they might spoil a work which was intended to do good in the hearts of man'.

A congregation of four hundred members, by this time reduced to one hundred as a result 
of an inter-tribal dispute in Tsewu's Johannesburg congregation, led Mzimba to the conclusion: 'They have joined the Independent or Ethiopian churches' (Mzimba to Stewart, 12/8/1896. UCTL, Stewart Papers, BC106:C167.8). At this time, Mzimba favoured following the procedures of the church and thus gained experience of the situation and circumstances of blacks in the Transvaal who enjoyed less legal protection than those in the Cape. On the issue of land, for instance, Tsewu believed 'that the Natives ought to be allowed to buy land in their own names, and have title deeds in their own names' (SANAC IV, 43,552:787). Mzimba concluded that 'uniting the native has increased the Ethiopian Church' (Mzimba to Stewart, 1/9/1896. UCTL SP BC106.C167). However, Brock's (1974:362) critique of the situation was, in a retrospective sense, prophetic: 'In the immediate past, as has been seen, the record of the mission in opposing discriminatory legislation had been fair, but they [ie. the missionaries] could not make a positive stance for equality within their own ecclesiastical domain'. Subsequent events were to prove how little they learned from the incident.

The inter-tribal dispute had resulted in the amaZulu withdrawing from the congregation leaving a majority of amaXhosa. This was followed by a dispute concerning a church building which Tsewu had erected. At its meeting at Burnshill on 14 November 1895, the Presbytery of Kaffraria received a report that led them to conclude that 'a change seemed desirable both for the sake of the mission and for the sake of Rev Tsewu' (Synod of Kaffraria, July 1897). On 16 July 1896, the Presbytery of Kaffraria decided that Tsewu should be replaced by Rev Elijah Makiwane of Macfarlan Mission, adjacent to Lovedale (Presbytery of Kaffraria, 16 July 1896; Synod of Kaffraria, July 1897;5). Tsewu refused and on 21 July 1896 sent a letter from a different group of his congregants to affirm that they were happy with his work (Millard 1999:73). Presbytery was rather sceptical about the source of the letter stating that it was 'purporting to be from his congregation' (Synod of Kaffraria, July 1897:5).

Revs Pambani Mzimba and James Stewart [Principal of Lovedale Institution] were sent as a commission to Johannesburg to investigate and Mzimba was to conduct services and provide pastoral care in Tsewu's congregation. Mzimba went alone and Stewart followed later. This was probably the first direct contact Mzimba had with the secessionary movement. In a letter to Stewart (12 August 1896. UCTL, Stewart Papers, BC106:C167.8) he stated:

I have now been three days my impression is that these men (the office-bearers) are going to separate themselves from the Free Church and that the congregation practically does not exist. Mr Tsewu represented I think that there was a membership of 400, I fear there is not even 100 now. They have joined the Independents and the Ethiopian churches and some time ago the Zulu left in a body. They have closed the door against services being held by me in the location Church which was built by Tsewu and the new one is not opened yet though completed. ... Ever since the Burnshill meeting [of Presbytery] the work of separating has been going on. ... The field is very important, money must not be grudged to give the cause a good start. What the Presbyterian Church now has is a church stand with an iron church building and rooms for a minister. Practically the work must be started afresh. All this is in the supposition that Mr Tsewu is removed or changed to another sphere of labour whether he should be removed or allowed to remain that will be the result of the investigation. The idea here is that he is already removed as he is practically suspended.

It seems clear that Tsewu was supported by at least some of his office-bearers. A subsequent letter of Mzimba to Stewart (11 September 1896. UCTL, Stewart Papers, BC106:C167.8) gives confusing figures regarding congregational statistics, though these figures probably relate to the different Free Church congregations (Tsewu's location church and the town congregation). The Zulus may have gone to the Congregationalist church as a result of the strong Congregationalist missionary activity in Natal and Zululand. However, at least Mzimba was able to operate in the 
town congregation of the Free Church;

The place open for me to preach is the town church because the stand belongs to the Free Church. There is a church at the location a few of Mr Tsewu's supporters have closed the church. It is plain they are leaving the Free Church where they are going to I do not know. The services are well attended. In the morning the church is nearly full. It holds about 250 . In the afternoon it is quite crowded and in the evening others cannot get in. A good many of these are strangers and others had left the Church, some have not returned they have gone to the Wesleyans, Ethiopian Church and Congregationalists.

This appears to be largely supposition on Mzimba's part, though it is probably true.

Mr Tsewu's salary is now due as he is paid monthly. The Treasurer Mr Bilbrough consulted the Deacons' Court they decided not to pay him until the moneys collected by Mr Tsewu are handed in. There are certain moneys in his hands This seems hard but I fear they may have no choice. Church moneys are not being collected or they are not given in at the Deacons' Court and therefore there is no money for paying the minister. And it is known that $\mathrm{Mr}$ Tsewu has certain monies given to him and that those who support him are not handing in any moneys. I understand Mr Tsewu has consulted lawyers and threatens to go to court. ... Church work especially finances is blocked that is endeavouring to have everything stopped that is if the seceding party succeeds. I think they will fail. They are not strong enough.

As was often the case in disputed situations, money became an issue and this hampered the work of mission and caused suspicion. It is not clear why Bilbrough consulted the Deacons' Court about whether or not to pay Tsewu if there were no funds available to do so. Whatever monies Tsewu held, they were never returned. 'It is noteworthy that Tsewu's actions, namely, his refusal to return church money, correspond closely to those later adopted by Mzimba himself' (Burchell 1979:121-122).

When Mr Tsewu went to the King William's Town Presbytery in July (1896) the Deacons' Court here (Johannesburg) had decided to open the new church which was finished on $9^{\text {th }}$ August. When I came here I went over to the location where special services were held by a man appointed by Mr Tsewu in the location church during the week. The man who had charge of the meeting asked me to address the meeting. I did so. This man Faka and another Japheth Mathews ordered the meeting to be closed and that they have the authority to lock the church. This was Monday evening the day I arrived $10^{\text {th }}$ August. The building belongs to Mr Tsewu but used by the congregation to hold services in. On Sabbath $16^{\text {th }}$ I preached in the town church as this is Presbytery property. It was not closed against me. The Deacons' Court when they met, they decided that the church be opened and that we hold services in but Faka and Mathew have the key, they could have had the church closed against me. ... I have been here now 4 Sabbaths a few partisans of Mr Tsewu's have closed that church. The rest of the people are most anxious that I should preach there as well as in town. However I have not gone to open the church. I shall wait your coming. There are people however in the location who are anxious that services be held (Mzimba to Stewart, 12 September 1896. UCTL, Stewart Papers, BC106:C167.9).

It is clear from this that not all of Tsewu's location congregation was opposed to Mzimba carrying out the functions assigned to him. The issue of ownership was also contentious as it would appear that Rev Tsewu had not funded the building since it was sanctioned by the Presbytery of Kaffraria and they would not have agreed to the erection of a building owned by an individual. The building would be owned by the General Trustees of the church. The use of the building would also have been an issue because in Free Church law, the minister has almost total control of their use except 'for any purpose not connected with the congregation, without the acquiescence both of the Session and the Deacons' Court' (BPCSA 1958:8,17-18). The BPCSA 
adopted Free Church law on its formation in 1923.

The commission sat during the latter part of September into October 1896. Tsewu accused James Stewart of undermining his work by diving the congregation by not hearing the witnesses in his defence. 'The evidence produce was very full' (Deposition² 1897:1). A report was submitted to the Presbytery meeting at Lovedale on 9 December 1896. As a result, Tsewu was cited to appear before the Presbytery on 22 January 1897 and was paid until the end of December 1896. Tsewu did not appear on the date cited but sent a telegram stating that he would arrive late. He did not arrive. On 16 April, Presbytery decided to institute a case of libel against Tsewu and he was cited to appear on 5 May 1897. Again, he did not appear. Neither did he appear on 21 May and 2 June when he was again cited to appear (Synod of Kaffraria 1897:6). In any case, the Presbytery referred to matter to the Synod for action. The charges were included in a slightly expanded form (Synod of Kaffraria 1897:6) but still without details. Despite this, the Presbytery decided that there was substance to the accusations, and Tsewu was accused of making false reports, not calling banns for marriages and charging unreasonable fees for performing marriages during the week. In addition he was accused of not acting according to church law and procedure in the election of elders and forcing members to pay church dues (Millard 1999:74). The Synod of Kaffraria noted in 1897 that 'for some time past the condition of the congregation under his care has been in an unsatisfactory state' (Deposition 1897:1) and that the charges were of a serious nature. The charges were 'wilful deception, abuse of ministerial functions, as well as dubious conduct in connection with various matters about church property' (Deposition 1897:2). These were very non-specific charges. Under these heads various comments were made but these were also non-specific though it is noted that 'A fuller statement will be found in another column containing the report of the meeting of Synod' (Deposition 1897:2). Sadly for Tsewu 'No counter evidence of any value against the many serious charges of very non-ministerial conduct was ever produced' (Deposition 1897:3). This was the first case of so serious a nature in the history of the Scottish Missions of the Free Church of Scotland in South Africa. The reason given for such a strong judgment was:

But for the credit of mission work and that of the native ministry as well as in justice to his unfortunate congregation ... and prevent him doing further mischief. If any error has been committed it is that of leniency, and of considerable delay in the hope that such a sentence might have been avoided (Deposition 1897:3).

Non-appearance, according to church law constituted an admission of guilt. So, due to Tsewu's non-appearance, the Synod decided to:

hold him as having confessed and to deal with him according to his offences - therefore the Synod did by their vote depose the said Edward Tsewu, like as they hereby do in the name of the Lord Jesus Christ, the alone King and Head of the Church, and in virtue of the power and authority committed by Him to them, depose the said Edward Tsewu, from the Office of the Holy Ministry; prohibiting and discharging him to exercise the same or any part thereof (Synod of Kaffraria 1897:7).

This decision was transmitted to the General Assembly of the Free Church of Scotland. Tsewu had allowed himself to be placed in a corner by the vagaries of church law by not appearing when requested to do so. Yet, it is strange that so harsh a sentence was meted out to him for a first offence by any legal standards. Perhaps this was meant to be a signal to like-minded ministers to warn them against similar action in the prevailing and growing secessionary movement (see above).

2 It is interesting that an article from the Christian Express [CE] was included in the Minutes of the Synod of Kaffraria as the official record of the Tsewu secession. The CE, published at Lovedale Institution, was the major ideological instrument of the Free Church of Scotland Mission. Its views were identical with those of the Mission. 
The Christian Express (August 1897) article, following the outcome of the Synod case ends with an apologia for the training of ministers: 'In the Presbyterian Church every precaution is taken by long training and moral supervision to prevent unsuitable men entering the work of the ministry. The moral failures have been comparatively few...' (Deposition 1897:4). This constitutes a damning indictment of Edward Tsewu. He had refused to attend Presbytery meetings giving various excuses including the death of his child and his brother-in-law which prevented him from leaving Johannesburg. These were considered inadequate reasons: 'Courts cannot postpone grave business for such a cause as Mr Tsewu pleads (Moir 1898:4). However, Tsewu's bereavements were substantial enough reasons according to African custom and culture. He was required again to appear before the presbytery and refused and resigned from the ministry.

The Rev WBJ Moir of Blythswood Institution and Moderator of Presbytery, wrote a negative review quoting directly from a document entitled 'Defence of the Rev Edward Tsewu of Johannesburg, on Dispute in Church Matters', a letter also reprinted in the Synod minutes from the Christian Express (Synod of Kaffraria, 1898). Moir had taught Tsewu at Lovedale and claimed to 'know most of his people' ('Defence', Synod of Kaffraria, 1898). Tsewu had claimed that he was not heard in his own defence. This was true. He had not had or taken the opportunity to defend himself. Moir (1898:2) challenged this by explaining that the Presbytery had devoted five days in February 1897 hearing Tsewu's defence in a preliminary enquiry in an informal setting, according to church law, to try to avoid a formal hearing. Moir (1898:2-3) is correct in his assertion that this was a hearing and not a trial, but with such patience 'that native auditors remarked to us we were having far too much patience with him'. This could not, however, be considered exoneration of the Courts of the church since they had well established procedures to follow. Then he tried to subvert the process by challenging the jurisdiction of the court and then resigning. He was the victim of deposition by default. Tsewu claimed that the problems which arose in his congregation were 'purposely and largely planned' (Moir 1898:3) to which Moir replied that it would be incomprehensible for the FCoS Mission to destroy its own missionary efforts or one of its ministers. Tsewu also claimed that his membership roll was greater than, in fact, it was and Moir (1898:3) gave downwardly revised figures drawn from the Communion Roll. To the charge that Dr Stewart had maliciously attacked Tsewu, Moir (1898:3) responded by saying that the charges had 'nearly all, brought by church-members and office-bearers. The words were the words of the Presbytery, but the facts were the facts of church-members and office-bearers'. Tsewu's charge was "The very point that caused a split in my church" was "the refusal of Dr Stewart to have the witnesses of the accused (myself) heard fairly"' (Moir 1898:304). But the division was evident before Stewart became involved and that was why Stewart was sent to Johannesburg.

Regarding the congregation's petition in favour of Tsewu, Moir (1898:5) reveals that it was not only Tsewu who was disciplined but also his office-bearers after colluding with him. He even admitted to the Presbytery that 'some came to him, and withdrew their names, when they heard the nature of the petition, and one or more of the names he erased with his own hand'.

\section{The Aftermath}

In response to his deposition, Tsewu established the Independent Native Presbyterian Church (SANAC IV, 43,774:787) Open for Reunion and, thereby, led the first secession from the FCoS. However, Tsewu did not regard it as a secession or schism. He made it quite clear to the South African Native Affairs Commission (14 October 1904, IV, 43,561:787; cf 43,562, 43772): 'The Independent Presbyterian Church is the separation [not secession] of our church from the Free Church on a church dispute at present, but we are open for re-union'. This constituted a prelude to the Mzimba Secession but in itself had little its long term effect. In the midst of all this, Tsewu 
then took his story to the press (Millard 1999:74), probably to expose the matter and solicit support for his cause. The sad situation arising out of Tsewu's discipline was exacerbated by his replacement by a white missionary, Rev CB Hamilton, as requested by the Presbytery of Kaffraria, supported by the Synod of Kaffraria, to the FMC. This decision of the Synod of Kafraria in 1899 worsened the situation. Rev John Lennox, writing to Dr Stewart commented:

Affairs in the Johannesburg congregation are at a deadlock. The office-bearers refuse to collect contributions even from those who are ready to give. It was felt by all in the Presbytery and Synod that a deputation should go there without delay, and Erskine and I were thought of. Stuart [of Burnshill] cannot leave his two stations and there is no one else who can go from this side, or who knows the circumstances fully (5 August 1899, UCTL Stewart Papers[SP] BC106: 167. 31).

It is not surprising that such problems arose considering the great distance between the Presbytery in the eastern Cape and Johannesburg. It was even difficult to be fully apprised of the intricacies of the situation.

Reverends PJ Mzimba and E Makiwane, raised the race issue by commenting on the Presbytery's, ie. white missionaries, view that 'The Free Church Native Congregation at Johannesburg is fit only for a white missionary' (15/4/1898-16/4/1898, Minutes of the Presbytery of Kaffraria, 14/4/1894-27/1/1900, Lennox Papers, UFH). Rev J Don, Clerk to the Presbytery of Kaffraria, in a letter to Lindsay, Secretary of the FMC of the FCoS, emphasised the inequality of whites and blacks, 'We cannot afford to act upon the assumption that the native is equal to the European' (24/1/1898, NLS:7798). Yet, Don did not see this as a factor in Tsewu's dispute, according to Tsewu: 'Before the late Mr Don died in King William's Town we spoke on that point, and he said to me, "So far as you are personally concerned, I know it is not a matter of white versus black". It was a church dispute' (SANAC IV, 43,621:793). Sundkler (1961:17) picks up this point:

the problem arises when the more repressive view tacitly or openly becomes dominating in churches which in principle are egalitarian or liberal but which, by "practical necessity" ie. consideration for the race-conscious White membership of a particular church, have to conform to a general segregation policy within the church.

This led Mzimba to conclude that black ministers would always be allocated subsidiary roles and never attain full equality with their white counterparts and that there was little hope of the development of a self-supporting, self-governing and self- propagating church. This became one of the main causes of the subsequent Mzimba Secession in 1898. In addition, the Tsewu Secession demonstrated that 'it was possible to disagree with the Presbyterian church authorities' (Millard 1995:215) and survive.

By 1903, the Johannesburg congregation was transferred to the care of the Transvaal Presbytery. Tsewu remained in Johannesburg and subsequently joined the American Methodist Episcopal Church (AMEC) contrary to his protestations about being a Presbyterian. Perhaps he had concluded that re-union was no longer a possibility after his replacement with a white minister. Millard (1999:74) notes that in 1905, Tsewu along with other AMEC members, Marshall Maxeke, John Mtshula and James Tantsi challenged the refusal of the Register of Deeds which would not register land on the name of an African by bypassing the official channels of the provincial administration and achieved his wish. This was significant for African Initiated Churches as it gave them the right to purchase land in urban areas. Millard (1999:74) affirms 'His desire for religious freedom became channelled into a struggle for political freedom'.

However, it is important to note that there were other localised secessions from the Free Church Mission in Qumbu, Port Elizabeth and Mafeking, all predating Mzimba's secession, perhaps demonstrating the potential of the Ethiopian movement as a national political movement. It was in this context that the better known Mzimba Secession occurred. 
One question that arises with regard to Edward is should he have been ordained in the first place given the misgivings about him, despite the pressures emanating from the policy to ordain black ministers? Either, he met the requirements or he did not. That he became a problem to the Synod and Presbytery of Kaffraria must be attributed in some measure to these courts of the FCoS. It also appears from the evidence available that Tsewu had a disruptive personality. There is no evidence that he tried to heal the rifts in his congregation. He was also defiant in the face of the Presbytery's attempts to bring him to justice, but clearly the parties were operating with differing concepts of what constituted justice. As in the case of other secessions, money became a confusing and complicating factor. Despite accusations to the contrary, Tsewu was not against European practice and influence. For instance, with regard to marriage, he took the view that he should 'encourage the Christian native in the way of marrying according to European custom' (SANAC IV, 43,579:789). As in other secessions, it appears that when a decision is made to separate from a parent body, there is no going back. Perhaps it would go beyond the evidence in this case to conclude that this was a matter of 'Pull up a good tree and push it outside'.

\section{BIBLIOGRAPHY}

Bantu Presbyterian Church of South Africa (BPCSA) 1958. Manual of the Bantu Presbyterian Church. Lovedale: Lovedale Press.

Brock S 1974. James Stewart and Lovedale: A reappraisal of missionary attitudes and African response in the Eastern Cape, South Africa, 1870-1905. (PhD thesis, Edinburgh: University of Edinburgh.

Burchell DE 1979. A history of the Lovedale Missionary Institution, 1890-1930. MA dissertation. Pietermaritzburg: University of Natal.

Claasen JW 1995. Independents made Dependents. Journal of Theology for Southern Africa, 95:15-34.

Cochrane JR 1987. Servants of Power: the role of the English speaking churches in South Africa 1903-1930. Johannesburg: Ravan.

Cuthbertson G 1987. Missionary Imperialism and Colonial Warfare: London Missionary Society attitudes to the South African War, 1899-1902. South African Historical Journal, 19:93-114.

Cuthbertson G 1991. "Cave of Adullam": Missionary Reaction to Ethiopianism at Lovedale, 1898-1902. Missionalia 19 (no.1, April): 57-64.

De Kock L 1996. Civilising Barbarians: missionary narrative and African textual response in nineteenth century South Africa. Johannesburg: Witwatersrand University Press.

Denis P 2011. Financial resources and economic agency in the early history of African Independent Churches. Studia Historiae Ecclesiasticae XXXVII (no.2):29-49.

Deposition of a Native minister (author unknown). Christian Express (August 1897, reprinted in University of Fort Hare (UFH), Howard Pym Africana Library (HPAL), Lennox Papers. Proceedings of the Synod of Kaffraria of the Free Church of Scotland, 1897.

Duncan GA 1997. Scottish Presbyterian Church Mission Policy in South Africa, 1898-1923. MTh dissertation. Pretoria: UNISA.

Hinchliffe P 1968. The Church in South Africa. London: SPCK.

Hofmeyr JW and Pillay GJ (Eds.) 1994. A History of Christianity in South Africa. Pretoria: Haum Tertiary.

Kärkäinen V-M 2002. An Introduction to Ecclesiology: Ecumenical, historical and global perspectives. Downer's Grove, Illinois: IVP Academic.

Lamola JM 1988. Towards a Black Church: a historical investigation of the African Independent Churches as a model. Journal of Black Theology in South Africa (JTSA)_2 (no.1, May): 5-14.

Lovedale Missionary Institution 1880-1883 . Annual Reports. Lovedale: Lovedale Press.

Millard JA 1995. A Study of the Perceived Causes of Schism in some Ethiopian-type Churches in the Cape and Transvaal, 1884-1925. (DTh thesis, Pretoria: UNISA).

Millard JA 1999. Malihambe - Let the Word spread. Pretoria: UNISA

Minutes and letterbooks of the FCoS. Edinburgh: National Library of Scotland. 
Moir WJB. Mr Edward Tsewu's 'Defence'. UFH, HPAL, Lennox Papers. Proceedings of the Synod of Kaffraria of the Free Church of Scotland, 1898.

Mothlabi M 1986. The Historical Origins of Black Theology, in Mosala IJ \& Tlhagale B, The Unquestionable Right to be Free: Essays in Black Theology. Johannesburg: Skotaville.

Odendaal A 1984. Vukani Bantu! : the beginnings of black protest politics in South Africa to 1912. Cape Town: David Philip.

South African Native Affairs Commission (SANAC 1903-1905). Minutes of Evidence and Proceedings (Vol. IV). Cape Town: Cape Times Ltd \& Government Printers.

Stewart J. James Stewart Papers. University of Cape Town Library (UCTL) BC106.C167.

Sundkler BGM 1961. Bantu prophets in South Africa. London: OUP.

Switzer L 1993. Power and Resistance in an African society: The Ciskei Xhosa and the Making of South Africa. Pietermaritzburg: University of Natal Press.

Tsewu E 1898. Defence of the Rev Edward Tsewu of Johannesburg, on Dispute in Church Matters. UFH, HPAL, Lennox Papers. Proceedings of the Synod of Kaffraria of the Free Church of Scotland, 1898. Lennox J 1897. University of Fort Hare (UFH), Howard Pym Africana Library (HPAL), Lennox Papers. Proceedings of the Synod of Kaffraria of the Free Church of Scotland, 1897.

Wilson F \& Perrot (Ed.) 1972. Outlook on a century: South Africa 1870-1970. Lovedale: Lovedale Press.

\section{KEY WORDS}

Ethiopianism

Free Church of Scotland

Lovedale Institution

Pambani Mzimba

Presbytery of Kaffraria

James Stewart

Synod of Kaffraria

Edward Tsewu 